\title{
Estimating Real Income in the United States from 1888 to 1994: Correcting CPI Bias Using Engel Curves
}

\section{Dora L. Costa}

Massachusetts Institute of Technology and National Bureau of Economic Research

\begin{abstract}
This paper provides the first estimates of overall CPI bias prior to the 1970 s and new estimates of bias since the 1970s. It finds that annual CPI bias was -0.1 percent between 1888 and 1919 and rose to 0.7 percent between 1919 and 1935. Annual CPI bias was 0.4 percent in the 1960 s and then rose to 2.7 percent between 1972 and 1982 before falling to 0.6 percent between 1982 and 1994. The findings imply that we have underestimated growth rates in true income in the 1920s and 1930 s and in the 1970 s.
\end{abstract}

\section{Introduction}

Accurately measuring changes in the cost of living is central to calculating real income; but the consumer price index (CPI) overstates increases in the true cost of living because it does not allow for substitution between goods in response to relative price changes, changes in consumer shopping patterns that shift purchases to discount stores, price declines in new goods prior to their late introduction in the CPI, and quality improvements in existing goods. Substitution bias is reduced in the chained gross domestic product and personal consumption expenditure deflators calculated by the Bureau of Economic Analysis, but

I have benefited from comments of workshop participants at Harvard, MIT, and the University of Chicago and of Robert Fogel, Jerry Hausman, Matthew Kahn, Eric Rasmusen, and William Wheaton. I have also benefited from the comments of John Cochrane (editor), Bruce Hamilton (referee), and an anonymous referee. I gratefully acknowledge the support of National Institutes of Health grant AG12658 and of the Russell Sage Foundation through its Visiting Scholar Program.

[Journal of Political Economy, 2001, vol. 109, no. 6]

(C) 2001 by The University of Chicago. All rights reserved. 0022-3808/2001/10906-0004\$02.50 
because these indexes depend on CPI prices, they too are likely to overstate increases in the cost of living. ${ }^{1}$

This paper provides the first estimates of overall annual CPI bias prior to the 1970s as well as new estimates of bias since the 1970s. The 1961 Stigler Commission concluded that virtually all economists would agree that there was upward bias in the various price indexes that they reviewed, but the commission presented no numerical estimates of bias (National Bureau of Economic Research 1961). The Boskin Commission (Boskin et al. 1998) argued that CPI bias is probably greater now than it was in the past because the number of goods has grown, because a greater rate of technological change is leading to more rapid price shifts, and because demand has shifted toward services and quality, making the task of measurement much harder. However, studies of CPI bias in specific goods or commodities suggest that bias may have been greater prior to the 1950s than afterward. Nordhaus (1997) estimates that the largest changes in the quality-adjusted price of lighting between 1800 and 1992 occurred between 1860 and 1950. Raff and Trajtenberg's (1997) study implies that most of the real change in the quality-adjusted price of autos between 1906 and 1982 occurred prior to 1940. Furthermore, the lag between the introduction of a new good and its inclusion in the CPI was longer in the prewar than in the postwar period. New cars were not introduced into the CPI until 1940, when close to 60 percent of households owned a car. Used automobiles were not introduced into the CPI until 1954. Refrigerators were not introduced into the CPI until 1934, when 40 percent of households owned a mechanical refrigerator and 30 percent of households owned an electric refrigerator (National Bureau of Economic Research 1961; Lebergott 1993). Finally, because the Bureau of Labor Statistics has been continually improving its calculation of the CPI, the procedures in place today are less likely to bias the CPI (Stewart and Reed 1999).

I calculate CPI bias by estimating the income elasticity of food and recreation using cross-sectional micro data pooled across all years in which consumer expenditure surveys are available and using these estimates to measure the increase in households' real income over time, controlling for changes in relative prices and in demographic characteristics. This procedure measures bias attributable to consumer substitution, increases in the durability of goods, the late introduction of

\footnotetext{
${ }^{1}$ The CPI is a Laspeyres index, which finds the cost of purchasing a fixed basket in a base period and the cost of buying the same basket in the present; therefore, it is upward biased because it does not allow for substitution between goods. Using a Paasche index, which finds the cost of purchasing a fixed basket of goods in the present and the cost of buying that basket in the past, would lead to downward bias. The Fisher Ideal index, a geometric mean of the Laspeyres and Paasche indexes, is used to calculate the GDP and personal consumption expenditure deflator. Weights vary from year to year.
} 
new goods into the CPI, changes in the distribution network, and the mismeasurement of prices. It cannot measure bias attributable to improvements in the quality of goods. I estimate overall CPI bias between the endpoints 1888-1919, 1919-35, 1960-72, 1972-82, and 1982-94 because the estimation approach that I use measures CPI bias between two or more years of consumer expenditure data and such machinereadable data are available for other years beginning only in the 1980s.

My most interesting results pertain to the 1920s and 1930s and the 1970s. My findings suggest that despite the income declines of the Great Depression, true total consumption expenditures were higher in 1935 than in 1919, not lower as suggested by CPI-deflated expenditures. My findings also suggest that there was no productivity slowdown in the 1970s, as indicated by both CPI-deflated personal expenditures and personal consumption expenditures deflated by a chained personal consumption expenditure deflator.

I begin the paper with a discussion of long-term trends in real per capita income and in expenditure shares devoted to food and to recreation. The empirical methodology is outlined in Section III. I then describe the data (Sec. IV) and present the results (Sec. V). Before concluding, I assess explanations for CPI bias (Sec. VI) and discuss the implications of the findings for true income levels and growth rates (Sec. VII).

\section{Trends}

Trends in the share of expenditures devoted to food and to recreation from the National Income and Product Accounts (NIPA) contraindicate the trend in real per capita personal expenditure and income deflated by the CPI in the 1920s and 1930s and the 1970s and 1980s (see fig. 1; income trends are not shown). After growing at a rate of 1.4 percentage points per year between 1900 and 1919, real personal expenditure per capita grew by only 1.2 percentage points per year between 1919 and 1929 before declining during the Great Depression. But although in 1935 real expenditure per capita was below its 1919 level, the expenditure share of food fell from 34 to 26 percent between these years and the share of recreation increased from 4 to 5 percent, implying that real expenditures were higher. Trends in food and recreation shares between 1972 and 1994 are comparable to those observed between 1950 and 1972 and suggest that growth rates between 1972 and 1994 were as high as those between 1950 and 1972 (3.0 percentage points per 

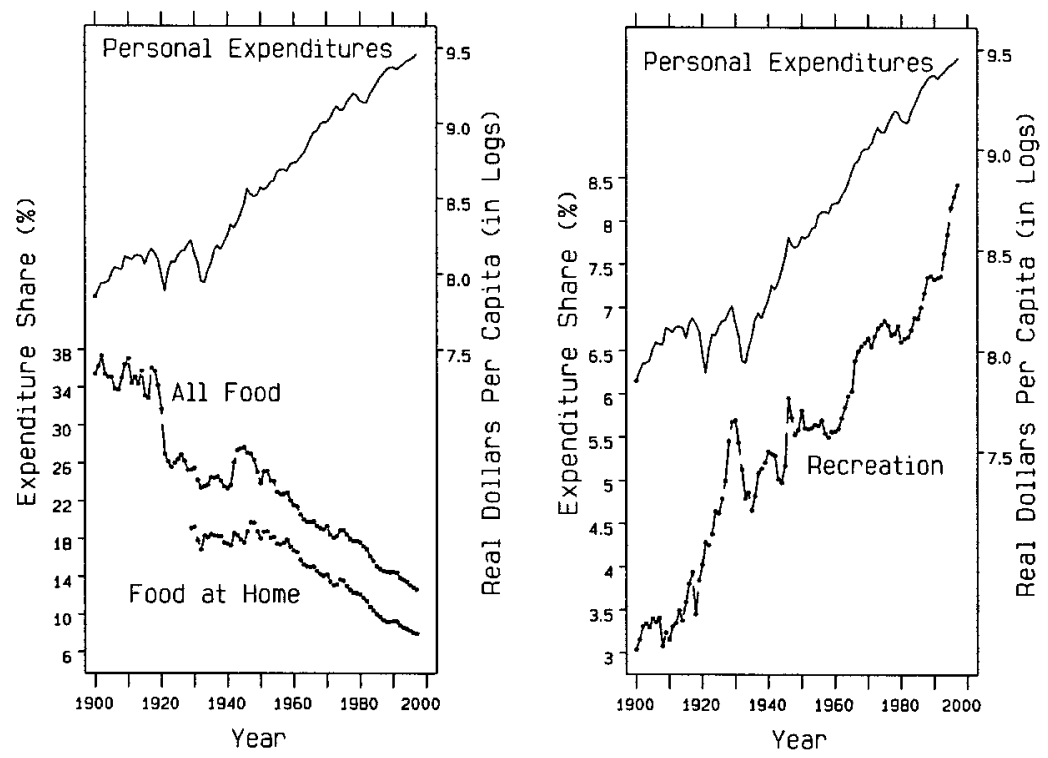

FIG. 1.-Real personal expenditures per capita and shares of personal expenditures devoted to food and recreation, 1900-1997. Figures for 1929-97 are taken from the NIPA and were obtained as a machine-readable file from the Dept. of Commerce. Total expenditures and expenditures on food and recreation prior to 1929 are taken from Lebergott (1996, pp. 148-53). Recreation includes entertainment and reading. Expenditures include not only those of individuals but also those of nonprofit institutions, private trust funds, and private health and welfare funds. All numbers are in constant 1982-84 dollars and are deflated using the CPI (see the BLS web site [http://www.bls.gov] and U.S. Bureau of the Census [1975, ser. E135-66, p. 210]).

year) even though measured growth rates were lower (1.8 percentage points per year). ${ }^{2}$

Inconsistency between trends in real expenditures and trends in food and recreation shares could arise from either CPI bias, changes in demographic characteristics, or declines in the relative prices of food and recreation. The relative price of food fell sharply during the Great Depression and the relative price of recreation fell during the first quarter

${ }^{2}$ Between 1950 and 1972 the share of food at home fell from 15 to 11 percent and the share of recreation rose from 6 to 7 percent. By 1994 the share of food at home stood at 7 percent and the share of recreation at 8 percent. Nakamura (1997) was the first to point out the steady decline in food's share and rise in recreation's share in total expenditures in the seemingly stagnant 1970s. Using the chained personal consumption expenditure deflator yields growth rates of 3.1 percent per year between 1950 and 1972 and 2.5 percent per year between 1972 and 1994, suggesting that most of the divergence in trends is due to CPI bias. Chained Fisher Ideal indexes prior to 1929 are unavailable. 
of the twentieth century. In the next sections I therefore formally control for price changes and for changes in demographic characteristics and argue that the remaining inconsistency between movements in expenditure shares and CPI-adjusted incomes is due to CPI bias.

\section{Empirical Methodology}

If the O'Gradys in 1919 had the same total CPI-deflated household expenditures as the Svensons in 1935 and both families had the same number of children, then I attribute differences in their food and recreation shares to CPI bias, controlling for changes in relative prices. The advantage of using food and recreation as indicator goods is that because their income elasticities are substantially different from one, their budget shares are sensitive to the mismeasurement of income. Food has the additional advantage of being a nondurable, implying that expenditures in one period cannot provide a flow of consumption in another. It also has the advantage of arguably being strongly separable from other goods in consumers' utility functions. Hamilton (2001) shows that to decompose food and nonfood expenditures into a price index and a utility (or "quantity") index requires assuming additive separability of food and nonfood in consumers' utility functions and homotheticity in the subutilities of food and nonfood. Provided that these conditions are met, CPI bias in such goods as cars will not affect food's budget share through any complementarities or substitutabilities. A disadvantage of food is that the reporting of food expenditures is sensitive to the survey method. Growth rates in food expenditure relative to total expenditure are larger in the NIPA than in the consumer expenditure surveys, and the magnitude of this difference was greater between 1973 and 1982 than between 1982 and 1994 (Triplett 1997). If the NIPA numbers are more accurate, I shall overestimate CPI bias between 1973 and 1982 relative to 1982 and 1994. Examining recreation provides corroboration for the results obtained using food but presents some additional difficulties. First, defining recreational goods is harder. For example, reading is included in my definition, but reading could be used for educational purposes as well. Second, the estimated relationship between the share of recreational expenditures and total expenditures changed considerably at the beginning of the twentieth century (Costa 1998). ${ }^{3}$ Because recreation requires time and because many of the complements to recreation such as public parks and sports facilities are publicly provided, estimated CPI bias using recreational shares will reflect changes in hours of work that are not attributable to

\footnotetext{
${ }^{3}$ The relationship between the food share and total expenditures is the same within but not across the prewar and postwar periods.
} 
rising incomes (e.g., changes in labor demand due to technological change) and in public investments. ${ }^{4}$ This is mainly a problem for the first half of the twentieth century.

Hamilton (2001) shows how to use different years of cross-sectional micro data to identify CPI bias. He presents specifications for the cases in which geographic and temporal variations in inflation rates of food and nonfood are available and in which they are not. Price variation arises from differences in relative inflation rates across regions because price indexes that allow for comparisons in the cost of living across regions are unavailable. Although my discussion is framed in terms of food and nonfood, any other indicator and nonindicator good could be used.

When both geographic and temporal variations in inflation rates are available, the empirical specification is

$$
\begin{aligned}
w_{i, j, t}= & \phi+\gamma\left[\ln \left(1+\Pi_{F, j, t}\right)-\ln \left(1+\Pi_{N, j, t}\right)\right] \\
& +\beta\left[\ln Y_{i, j, t}-\ln \left(1+\Pi_{j, t}\right)\right]+\mathbf{X}^{\prime} \theta \\
& +\sum_{t=1}^{T} \delta_{t} D_{t}+\sum_{j=1} \delta_{j} D_{j}+u_{i, j, t}
\end{aligned}
$$

where the subscripts refer to an individual household $i$, to region $j$, to time period $t$, to food $F$, and to nonfood $N$; $w$ is the share of food in total expenditures; $\Pi_{F, j, t}, \Pi_{N, j, t}$ and $\Pi_{j, t}$ represent the cumulative percentage increase in the CPI-measured price of food, nonfood, and all goods in region $j$ from year 0 to year $t ; Y$ is total expenditures; $\mathbf{X}$ is a vector of individual household characteristics; the $D_{t}$ are time dummies measuring CPI bias and the $D_{j}$ are regional dummies; and $u$ is an error term. Note that equation (1) should include a control for the price of restaurant meals, unless food at home and food eaten out are perfect substitutes. However, long-run indices for restaurant meals are unavailable. Using food at home as the dependent variable and including the budget share of food eaten out in the matrix $\mathbf{X}$ provides an ad hoc fix. I use total food as an independent variable as well (without any ad hoc fixes) because it is the only food indicator available in $1888-90 .^{5}$

Without geographic variation in the price of food, equation (1) becomes

\footnotetext{
${ }^{4}$ The changing nature of recreation presents an additional difficulty. For example, if there is more scope for price discrimination among suppliers of live entertainment than among suppliers of radio or television, then the shift from live entertainment to broadcasts could increase consumer surplus.

${ }^{5}$ Because the share of food eaten out was small in the 1910s (less than 3 percent of all food expenditures according to the survey of consumer expenditures undertaken in 1917-19) and probably even smaller in the 1890s, this should not materially affect the bias results for the end of the nineteenth century and the beginning of the twentieth.
} 


$$
w_{i, t}=\phi+\beta\left[\ln Y_{i, t}-\ln \left(1+\Pi_{t}\right)\right]+\mathbf{X}^{\prime} \theta+\sum_{t=1}^{T} \delta_{t} D_{t}+u_{i, t}
$$

An advantage of this specification is that it easily accommodates different functional forms, such as

$$
\begin{aligned}
w_{i, t}= & \phi+\beta_{1}\left[\ln Y_{i, t}-\ln \left(1+\Pi_{t}\right)\right]+\beta_{2}\left[\ln Y_{i, t}-\ln \left(1+\Pi_{t}\right)\right]^{2} \\
& +\mathbf{X}^{\prime} \theta+\sum_{t=1}^{T} \delta_{t} D_{t}+u_{i, t}
\end{aligned}
$$

Calculating the cumulative percentage of CPI bias at time $t$ is straightforward. Consider first the case of equation (1). Because

$$
\delta_{t}=\gamma\left[\ln \left(1+E_{F, t}\right)-\ln \left(1+E_{N, t}\right)\right]-\beta E_{t},
$$

then, under the assumption that the relative bias between food and nonfood is constant across years and that the price of food and nonfood is equally biased,

$$
\ln \left(1+E_{t}\right)=\frac{-\delta}{\beta} .
$$

The cumulative percentage of CPI bias at time $t$ is therefore

$$
1-\exp \left(\frac{-\delta}{\beta}\right) \text {. }
$$

If food is less badly biased than nonfood (as seems likely), then equation (4) will understate the bias. If food is more badly biased, then equation (4) will overstate the bias. Next, consider equation (2). For a given $\gamma$ and relative price changes, the cumulative percentage of CPI bias at time $t$ is

$$
1-\exp \left\{\frac{\delta-\gamma\left[\ln \left(1+\Pi_{F, t}\right)-\ln \left(1+\Pi_{N, t}\right)\right]}{-\beta}\right\} .
$$

In the case of equation (3), when I correct for relative price changes, cumulative CPI bias at time $t$ becomes

$$
1-\exp \left(\frac{\beta_{1} \pm \sqrt{\beta_{1}^{2}-4 \beta_{2}\left\{-\delta_{t}+\gamma\left[\ln \left(1+\Pi_{F, t}\right)-\ln \left(1+\Pi_{N, t}\right]\right\}\right.}}{2 \beta_{2}}\right) .
$$

Equations (1), (2), and (3) are derived from the basic demand structure,

$$
w_{i, j, t}=\phi+\gamma\left(\ln P_{F, j, t}-\ln P_{N, j, t}\right)+\beta\left(\ln Y_{i, j, t}-\ln P_{j, t}\right)+\mathbf{X}^{\prime} \theta+u_{i, j, t},
$$

where $P_{F, j, b} P_{N, j, t}$ and $P_{j, t}$ represent the true but unobserved prices of food, 
nonfood, and all goods. Suppose that the true cost of living is a weighted average of food and nonfood,

$$
\ln P_{j, t}=\alpha \ln P_{F, j, t}+(1-\alpha) \ln P_{N, j, t},
$$

and that all prices of a good $G$ (either food, nonfood, or all goods) are measured with error,

$$
\ln P_{G, j, t}=\ln P_{G, j, 0}+\ln \left(1+\Pi_{G, j, t}\right)+\ln \left(1+E_{G, t}\right),
$$

where $\Pi_{G, j, t}$ is the cumulative percentage increase in the CPI-measured price of $G$ in region $j$ from year 0 to year $t$ and $E_{G, t}$ is the year $t$ percentage of measurement error in cumulative inflation (assumed to be constant across regions). Because aggregate error is a weighted average of the error in food and nonfood,

$$
\ln \left(1+E_{t}\right)=\alpha\left(1+E_{F, t}\right)+(1-\alpha) \ln \left(1+E_{N, t}\right) .
$$

When equation (7) is rewritten as

$$
\begin{aligned}
w_{i, j, t}= & \phi+\gamma\left[\ln \left(1+\Pi_{F, j, t}\right)-\ln \left(1+\Pi_{N, j, t}\right)\right] \\
& +\beta\left[\ln Y_{i, j, t}-\ln \left(1+\Pi_{j, t}\right)\right]+\mathbf{X}^{\prime} \theta \\
& +\gamma\left[\ln \left(1+E_{F, t}\right)-\ln \left(1+E_{N, t}\right)\right]-\beta E_{t} \\
& +\gamma\left(\ln P_{F, j, 0}-\ln P_{N, j, 0}\right)-\beta P_{j, 0}+u_{i, j, t},
\end{aligned}
$$

equation (1) follows directly.

\section{Data}

In 1888-90 the U.S. Department of Labor undertook the first nationwide consumer expenditure survey. I use this survey, as well as those of $1917-19,1935-36,1960-61,1972-73$, and $1980-94 .{ }^{6}$ The postwar surveys cover a representative sample of the U.S. population but were implemented differently. The 1980 and 1981 surveys are not as reliable as the other surveys. The prewar surveys were more specialized. (See the Data Appendix for a discussion of differences between surveys.) One major difference is that the early surveys did not cover "slum or charity" families, and those before 1935 did not cover higher-income families. These differences in population coverage will not affect estimates of

\footnotetext{
${ }^{6}$ The surveys used in this paper are the Department of Labor's Cost of Living of Industrial Workers in the United States and Europe (1888-90); the Bureau of Labor Statistics' Cost of Living in the United States (1917-19); the Department of Labor and Department of Agriculture's Study of Consumer Purchases in the United States (1935-36); the Department of Labor's Consumer Expenditure Survey (1960-61); the Survey of Consumer Expenditures 1972-73); and John Sabelhaus' Consumer Expenditure Survey Family Level Extracts (1980:1-1995:1).
} 
CPI bias, provided that there is enough overlap in income across surveys, because identification comes from comparing food and recreation expenditure shares of households with the same inflation-adjusted income controlling for demographic characteristics.

I impose several restrictions on the samples both to exclude suspect observations and observations in which food demand may be unusual and to obtain more comparable populations across surveys. I restrict all surveys to urban families, to husband and wife families, to families in the postwar period that were not receiving welfare or food stamps, to families in which the husband was aged 21-64, and to families in which the husband was in the labor force. I exclude observations in which the share of expenditures devoted to food was less than 0.05 or greater than 0.8 and in which the share of expenditures devoted to recreation was greater than $0.7 .^{7}$ In the postwar period I also exclude families containing adults over age 25 other than the husband and wife.

I create regional price indexes for four census regions for all items, for food, for nonfood beginning in 1917, and for recreation and nonrecreation beginning in 1960 . These indexes can be used to compare changes in the cost of living across census regions. The Data Appendix details their construction. Inflation adjustment for the 1972-73 and 1960-61 surveys is for two different years, for the 1935-36 survey for one year only (the survey predominantly covers expenditures in 1935), and for the 1917-19 survey on a monthly basis because of high wartime inflation and because households were surveyed in different months. The exact survey dates of individual households in the 1888-90 study are not known, but this should not affect estimates of CPI bias because the price level was fairly constant between these years.

The dependent variables that I use in the estimation are the share of expenditures devoted to food eaten at home, the share of expenditures devoted to all food, and the share of expenditures devoted to recreation. Expenditures for food at home are not known in 1888-90. Recreation includes entertainment and reading expenditures, but not expenditures on vacation lodging, food, or travel. Beginning in 1972-73 it also includes expenditures on such items as boats, aircraft, and wheel goods.

Control variables include real total expenditures, relative price changes, the share of food eaten out (when the dependent variable is food eaten at home), demographic characteristics, time dummies, and region dummies (for four census regions). I use total expenditures rather than income because expenditures better reflect permanent income. The full set of time dummies consists of dummies for 1888-90,

\footnotetext{
${ }^{7}$ Excluding households in which the share of expenditures was less than 0.05 excludes only 0.2 percent of households in 1960 and 0.6 percent of households in 1994 .
} 
1917-19, 1935, 1960, 1961, 1972, and 1973 and individual dummies for each of the years 1980-94. Demographic controls include the age of the husband, the age of the wife (unknown in 1960-61), and a dummy variable equal to one if the husband is nonwhite (unknown in 1888-90). With the exception of the 1960-61 survey, I know the total number of children and the total number of household members other than the husband and wife above age 18. In all years except for $1960 \mathrm{I}$ also know the number of children under age 2, the number of boys aged 2-15, the number of girls aged 2-15, the number of boys aged 16-17, and the number of girls aged 16-17. When I use the 1960-61 survey, I therefore use a more limited set of demographic controls, and in all other years I use a fuller set of demographic controls. ${ }^{8}$

The final step in the construction of the data set requires merging two or more years of consumer expenditure data because using the time dummy approach measures CPI bias between two adjacent survey dates. If the underlying parameter estimates were stable, all the survey years could be pooled together. But because a century is a long time and because the surveys were collected in slightly different ways, I need to verify which surveys can be pooled together. The rule that I follow in determining which consumer expenditure surveys can be pooled is to pool if the inclusion of an additional survey does not change the CPI bias results. This procedure suggests that when food is the regressor, I can legitimately pool the 1960-94 data and the 1888-1935 data, but not the 1935 data with later data. When recreation is the regressor, I cannot pool the 1888 and 1935 data. I therefore use Hamilton's (2001) methodology to ascertain the extent of CPI bias for 1888-1935 and 1960-94, but not for 1935-60.

\section{Results}

I estimate CPI bias between 1888-1935 and 1960-94 using both the empirical specification that allows for geographic variation in relative price changes (eq. [1]) and the empirical specification with no geographic variation (eq. [2]). Because regional price indexes for all items and for food are unavailable prior to 1917 and for recreation prior to 1952, I use the specification without geographic price variation for the 1888-1917 data when the dependent variable is either all food or recreation and for the 1917-35 data when the dependent variable is the recreation expenditure share. I use the specification with geographic price variation for the 1917-35 data and the 1960-94 data when the

${ }^{8}$ Using a more limited set of controls does not materially affect the bias estimates. I do not include the work status of the wife as a control variable. Only 3 percent of wives in the early surveys worked. In the later surveys the inclusion of wife's work status leads to collinearity problems with the share of food eaten out and the year dummies. 
TABLE 1

Selected Regression Coefficients, Food Regressions

\begin{tabular}{|c|c|c|c|c|c|}
\hline & \multicolumn{2}{|c|}{ Food Aт Номе } & \multicolumn{3}{|c|}{ All FoOd } \\
\hline & $1917-35$ & 1960-94 & $1888-1919$ & 1919-35 & 1960-94 \\
\hline $\begin{array}{l}\text { Log(total } \\
\text { expendi- } \\
\text { tures) }\end{array}$ & $\begin{array}{c}-.128 * \\
(.001)\end{array}$ & $\begin{array}{c}-.090^{*} \\
(.001)\end{array}$ & $\begin{array}{l}-.129 * \\
(.002)\end{array}$ & $\begin{array}{c}-.114^{*} \\
(.001)\end{array}$ & $\begin{array}{c}-.076^{*} \\
(.001)\end{array}$ \\
\hline $\begin{array}{l}\log \text { (relative } \\
\text { food price) }\end{array}$ & $\begin{array}{l}.005^{*} \\
(.002)\end{array}$ & $\begin{array}{l}.007 \\
(.018)\end{array}$ & & $\begin{array}{l}.006^{*} \\
(.002)\end{array}$ & $\begin{array}{c}-.008 \\
(.020)\end{array}$ \\
\hline $\begin{array}{l}\text { Share of food } \\
\text { eaten out }\end{array}$ & $\begin{array}{r}-.306^{*} \\
(.017)\end{array}$ & $\begin{array}{c}-.181^{*} \\
(.010)\end{array}$ & & & \\
\hline $\begin{array}{l}\text { Dummy }=1 \text { if } \\
\text { year is } \\
1917-19\end{array}$ & & & $\begin{array}{l}.004^{*} \\
(.002)\end{array}$ & & \\
\hline $\begin{array}{l}\text { Dummy }=1 \text { if } \\
\text { year is } 1935\end{array}$ & $\begin{array}{c}-.016^{*} \\
(.001)\end{array}$ & & & $\begin{array}{c}-.009 * \\
(.002)\end{array}$ & \\
\hline $\begin{array}{l}\text { Dummy }=1 \text { if } \\
\text { year is } 1972\end{array}$ & & $\begin{array}{c}-.004^{*} \\
(.001)\end{array}$ & & & $\begin{array}{l}.002 \\
(.003)\end{array}$ \\
\hline $\begin{array}{l}\text { Dummy }=1 \text { if } \\
\text { year is } 1982\end{array}$ & & $\begin{array}{r}-.034^{*} \\
(.002)\end{array}$ & & & $\begin{array}{c}-.036^{*} \\
(.002)\end{array}$ \\
\hline $\begin{array}{l}\text { Dummy }=1 \text { if } \\
\text { year is } 1994\end{array}$ & & $\begin{array}{c}-.044^{*} \\
(.002)\end{array}$ & & & $\begin{array}{c}-.047 * \\
(.002)\end{array}$ \\
\hline Adjusted $R^{2}$ & .609 & .516 & .354 & .472 & \\
\hline
\end{tabular}

NoTE. -Standard errors are in parentheses. The 1888-1919 data contain 14,653 observations, the 1919-35 data 14,284 observations, and the 1960-94 data 26,420 observations. Population weights were created and used in the estimation. Additional controls for the 1888-90 regression include the age of the husband and wife, the number of children under age 2 , the number of boys aged 2-15, the number of girls aged 2-15, the number of boys aged 16-17, the number of age 2 , the number of boys aged $2-15$, the number of girls aged $2-15$, the number of boys aged 16-17, the number of
girls aged 16-17, and the number of household members over age 18 (other than the husband and wife). The 1917-35 data include the same controls but also include a dummy if the household was nonwhite and regional dummies. The 1960-94 data are limited to fewer controls and include controls for the age of the husband, the total number of children under age 18, the total number of children squared, the number of household members over age 18, a dummy equal to one if the household was nonwhite, regional dummies, and individual year dummies for 1961, 1973, 1980-81, and 1983-93. The full set of demographic controls is given in Costa (2000).

* Significant at the 1 percent level.

dependent variable is the food expenditure share. I also use this specification for the 1972-94 data when the dependent variable is the recreation expenditure share, limiting myself to these years because the definition of recreation in the 1960-61 survey was not comparable to later definitions. For recreation in 1972-94, I also use the empirical specification without geographic price variation that is quadratic in expenditures (eq. [3]).

Tables 1 and 2 present selected regression coefficients for the food and recreation regressions. In all years, the specification in which the expenditure share of food at home is the dependent variable has the best fit and the specification in which the dependent variable is recreation has the poorest fit. The control variables have the expected sign. The greater the share of food eaten out, the lower the share of food eaten at home. Demographic variables (not shown) indicate that the greater the number of children in the household, the greater the food expenditure share. Older children increase the share of expenditures devoted to food by more than children under age 2 . Children decrease 
TABLE 2

Selected Regression Coefficients, Recreation

\begin{tabular}{|c|c|c|c|c|}
\hline & \multirow[b]{2}{*}{$1888-1919$} & \multirow[b]{2}{*}{$1919-35$} & \multicolumn{2}{|c|}{ 1972-94 } \\
\hline & & & (1) & (2) \\
\hline $\log$ (total expenditures) & $\begin{array}{l}.023^{*} \\
(.001)\end{array}$ & $\begin{array}{l}.015^{*} \\
(.005)\end{array}$ & $\begin{array}{l}.023^{*} \\
(.001)\end{array}$ & $\begin{array}{l}.053^{*} \\
(.017)\end{array}$ \\
\hline $\begin{array}{l}\text { Log(total expenditures) } \\
\text { squared }\end{array}$ & & & & $\begin{array}{l}-.002^{* * *} \\
(.001)\end{array}$ \\
\hline $\begin{array}{l}\log (\text { relative recreation } \\
\text { price) }\end{array}$ & & & $\begin{array}{l}.046^{*} \\
(.018)\end{array}$ & \\
\hline $\begin{array}{l}\text { Dummy }=1 \text { if year is } \\
1917-19\end{array}$ & $\begin{array}{l}.003^{*} \\
(.001)\end{array}$ & & & \\
\hline $\begin{array}{l}\text { Dummy } \\
1935\end{array}$ & & $\begin{array}{l}.003^{*} \\
(.001)\end{array}$ & & \\
\hline $\begin{array}{l}\text { Dummy }=1 \text { if year is } \\
1982\end{array}$ & & & $\begin{array}{l}.011^{*} \\
(.004)\end{array}$ & $\begin{array}{l}.003 \\
(.002)\end{array}$ \\
\hline $\begin{array}{l}\text { Dummy }=1 \text { if year is } \\
1994\end{array}$ & & & $\begin{array}{l}.019^{*} \\
(.004)\end{array}$ & $\begin{array}{l}.012 * \\
(.002)\end{array}$ \\
\hline Adjusted $R^{2}$ & .153 & .099 & .072 & .069 \\
\hline
\end{tabular}

Note.-Standard errors are in parentheses. The 1888-1919 data contain 14,653 observations, the 1919-35 data 14,284 observations, and the 1972-94 data 23,412 observations. Population weights were created and used in the estimation. Additional controls include the age of the husband and wife, the number of children under age 2 , the number of boys aged $2-15$, the number of girls aged $2-15$, the number of boys aged 16-17, the number of girls aged 16-17, and the number of household members over age 18 (other than the husband and wife). The 1917-19 and 1972-94 regressions include a dummy equal to one if the household was nonwhite. The 1972-94 regressions include individual year dummies for 1961, 1973, 1980-81, and 1983-93. The full set of demographic controls is given in Costa (2000).

* Significant at the 1 percent level.

** Significant at the 10 percent level.

the share of recreational expenditures, but in the 1917-35 and the 1972-94 data, the number of boys in some age groups increases the share of recreational expenditures. Both food and recreation expenditures are lower for nonwhites (though neither significantly nor materially for recreation in 1917-35).

The regression results yield reasonable estimates of expenditure and price elasticities. The estimated expenditure elasticities for food at home are 0.47 in 1960-94 and 0.62 in 1917-35. Those for total food are 0.65 in 1960-94 and 0.68 in 1917-35 and in 1888-1917. The expenditure elasticities for recreation are 1.37 in 1972-94, 1.41 in 1917-35, and 1.82 in $1888-1917 .{ }^{9}$ The price elasticities for food eaten at home are -0.87 in 1960-94 and -0.85 in 1917-35. Those for all food are -0.96 in $1960-94$ and -0.87 in $1917-35$. The price elasticity of recreation is -0.29 in $1960-94 .^{10}$ The coefficient on the price of food relative to

\footnotetext{
${ }^{9}$ Expenditure elasticities were calculated as $1+(\beta / w)$. If $\beta$ is biased because total expenditures are measured with error, then CPI bias will be measured with error as well. Using household income as an instrumental variable would entail making assumptions about the relationship between permanent and transitory income. Hausman, Newey, and Powell (1995) used future consumption and found that both the instrumental variable and ordinary least squares results accurately estimated the elasticities.

${ }^{10}$ Price elasticities are calculated as $-1+[(\gamma-\alpha \beta) / w]$, where $\alpha$ is the share of the indicator good in the total price index.
} 
TABLE 3

Summary of Bias Estimates, 1888-1994

\begin{tabular}{|c|c|c|c|c|c|c|}
\hline & \multicolumn{4}{|c|}{ Cumulative Bias Based on: } & \multirow{2}{*}{\multicolumn{2}{|c|}{$\begin{array}{l}\text { ANNUAL } \\
\text { Bias (\%) }\end{array}$}} \\
\hline & \multirow[b]{2}{*}{ Food at Home } & \multirow[b]{2}{*}{ All Food } & \multicolumn{2}{|c|}{ Recreation } & & \\
\hline & & & (1) & (2) & Best Fit & Range \\
\hline $\begin{array}{l}1888 / 90-1917 / 19 \text { (no price } \\
\text { adjustment) }\end{array}$ & & $\begin{array}{l}-.032 \\
(.012)\end{array}$ & $\begin{array}{l}.089 \\
(.021)\end{array}$ & & -.1 & $-.1-.3$ \\
\hline $\begin{array}{l}1888 / 90-1917 / 19 \text { (price } \\
\text { adjusted) }\end{array}$ & & $\begin{array}{l}-.035 \\
(.013)\end{array}$ & & & -.1 & -.1 \\
\hline $\begin{array}{c}1917 / 19-1935 / 36 \text { (recrea- } \\
\text { tion not price adjusted) }\end{array}$ & $\begin{array}{l}.118 \\
(.010)\end{array}$ & $\begin{array}{l}.076 \\
(.013)\end{array}$ & $\begin{array}{l}.191 \\
(.033)\end{array}$ & & .7 & $.4-1.1$ \\
\hline $1960-72$ & $\begin{array}{l}.043 \\
(.024)\end{array}$ & $\begin{array}{l}-.022 \\
(.033)\end{array}$ & & & .4 & $-.2-.4$ \\
\hline $1972-82$ & $\begin{array}{l}.269 \\
(.025)\end{array}$ & $\begin{array}{l}.394 \\
(.034)\end{array}$ & $\begin{array}{l}.378 \\
(.103)\end{array}$ & $\begin{array}{l}.187 \\
(.034)\end{array}$ & 2.7 & $1.9-3.9$ \\
\hline 1982-94 & $\begin{array}{l}.073 \\
(.018)\end{array}$ & $\begin{array}{l}.014 \\
(.021)\end{array}$ & $\begin{array}{l}.188 \\
(.032)\end{array}$ & $\begin{array}{l}.122 \\
(.033)\end{array}$ & .6 & $.1-1.6$ \\
\hline 1972-94 & $\begin{array}{l}.343 \\
(.033)\end{array}$ & $\begin{array}{l}.408 \\
(.033)\end{array}$ & $\begin{array}{l}.566 \\
(.067)\end{array}$ & $\begin{array}{l}.309 \\
(.033)\end{array}$ & 1.6 & $1.4-2.6$ \\
\hline 1960-94 & $\begin{array}{l}.386 \\
(.015)\end{array}$ & $\begin{array}{l}.455 \\
(.018)\end{array}$ & & & 1.1 & $1.1-1.3$ \\
\hline
\end{tabular}

NotE.-Annual bias estimates from the best-fitting regressions pertain to food between 1888 and 1919 and food at home for the other years. Standard errors are in parentheses. The price adjustment for $1888 / 90-1917 / 19$ used the value of $\gamma=.006$ from the 1917/19-1935/36 regression and assumed that movement in the relative CPI price of food mirrored that in the relative wholesale price of food (ser. E 40-51 in U.S. Bureau of the Census [1975, p. 200]). As noted in the text, using a larger value of $\gamma$ would yield a larger, negative estimate of annual bias. Correcting the prewar estimates for changes in the relative price of recreation using $\gamma=.046$ derived from the 1972-94 recreation equation yields larger estimates of cumulative bias. The second specification that used recreation as an indicator good contained

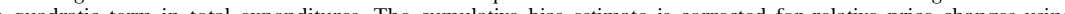
quadratic term in total expenditures. The cumulative bias estimate is corrected for relative price changes using $\gamma=.046$. For a price index for recreation prior to 1935 , see Owen $(1970$, p. 85$)$.

nonfood is not precisely estimated in 1960-94. Restricting the data to 1972-94 yields statistically significant and larger coefficients on relative prices $(\gamma=0.031$ for food at home), and these coefficients, together with the specification without geographic price variation, can be used to obtain alternative estimates of CPI bias.

Table 3 summarizes cumulative bias estimates and, where applicable, presents estimates corrected for relative price changes.

The CPI bias was minimal during the 1888-1919 period. Using the specification for food yields bias estimates of -0.1 percent per year, even after correcting for relative price changes using the estimate of $\gamma=0.006$ from the 1917-35 regression. Dropping from the sample individuals who had income from gardens or animals and therefore may have had some self-sufficiency in food yields an estimate of zero. Using the estimate of $\gamma=0.031$ derived from the 1972-94 data yields a cumulative bias estimate of $-0.049(\hat{\sigma}=0.013)$ or -0.2 percent per year. Using recreation as an indicator good and not adjusting for prices suggests that annual CPI bias was 0.3 percent. Adjusting for relative price changes using the estimate of $\gamma=0.046$ from the 1972-94 regression 
suggests that cumulative CPI bias was $0.384(\hat{\sigma}=0.011)$ and that annual bias was 1.3 percent. However, differences in the total expenditure elasticity of recreation between 1888-1919 and 1960-94 suggest definite changes in functional form, so it may not be possible to use an estimate of $\gamma$ derived from modern data.

The CPI was biased between 1917 and 1935. The specification that uses the share of food at home as a dependent variable suggests that annual bias was 0.7 percent per year. The specification that uses all food as an indicator good yields the smaller annual bias estimate of 0.4 percent. Dropping from the sample individuals who had incomes from gardens or animals yields annual estimates of CPI bias of 0.8 and 0.6 when food at home and total food, respectively, are used as indicator goods. Using food at home as the indicator good and the specification without geographic price variation yields a cumulative bias estimate of $0.137(\hat{\sigma}=0.017)$ when $\gamma=0.005$ and an estimate of $0.083(\hat{\sigma}=$ 0.018 ) when $\gamma=0.031$, or 0.9 and 0.5 percent per year, respectively. The specification that uses recreation as an indicator good yields the larger estimate of 1.1 percent per year with no relative price adjustment. Correcting for relative price changes using the estimate of $\gamma$ from the 1972-94 regression suggests that cumulative CPI bias was $0.561(\hat{\sigma}=$ $0.023)$, or 3.1 percent per year. Excluding from the sample households that in 1917-19 lived in smaller cities and therefore may have had fewer opportunities for market recreation does not change the results. Using the Engel curve specification that is quadratic in total expenditures yields estimates of CPI bias (after correcting for relative price movements) of 0.9, 0.7, and 3.3 percent when food at home, all food, and recreation, respectively, are used as indicator goods. Using recreation rather than food as an indicator good may lead to a bigger estimate of CPI bias because recreational goods are harder to define, because recreation may be more badly biased than nonrecreation, or because estimated CPI bias is additionally indicating improvements in household living standards arising from increases in leisure time and in the public provision of recreation.

The CPI bias has fluctuated in the postwar period. Bias was relatively low in the 1960s and high thereafter. Using the share of food eaten at home as an indicator good suggests that CPI bias was 0.4 percent per year between 1960 and 1972, but it was 2.7 percent per year between 1972 and 1982 and 0.6 percent per year between 1982 and 1994. Overall bias between 1972 and 1994 was 1.6 percent. Using the specification without geographic price variation and the estimate of 0.031 for $\gamma$ derived from the 1972-94 data implies that CPI bias was 0.5 percent between 1960 and 1972 and 1.5 percent between 1972 and 1994. Using all food as an indicator good yields a larger estimate of bias between 1960 and 1994. When I use recreation as an indicator good and use the 
specification given in equation (1), I obtain a larger overall estimate of CPI bias between 1972 and 1994. When I use the Engel curve specification that is quadratic in the logarithm of total expenditures (eq. [3]) and correct for relative price changes, I obtain an estimate of bias of 1.4 percent per year between 1972 and 1994.

Estimates of CPI bias in the 1970s and early 1980s are not sensitive to the choice of later endpoints. For example, picking 1983 as the endpoint implies that CPI bias was 2.8 percent per year between 1972 and 1983. Picking 1984 implies that it was 2.5 percent per year between 1972 and 1984. Earlier endpoints are not used because, as discussed in the Data Appendix, 1980 and 1981 are not reliable. ${ }^{11}$

The data suggest that in the prewar period, CPI bias was much larger for African Americans than it was for whites. Between 1919 and 1935, cumulative CPI bias estimated for the sample of white families was only $0.061(\hat{\sigma}=0.011)$, whereas for the sample of black families it was 0.565 $(\hat{\sigma}=0.072)$. Although cumulative bias is precisely estimated, the 1935 data contain only 152 black households, so the results may depend on the particular sample. In the postwar period, there were no detectable differences in CPI bias for black and white households, in contrast to Hamilton's (2001) results, based on the Panel Study of Income Dynamics, of greater CPI bias for blacks than for whites.

\section{Explaining CPI Bias}

The previous section showed that CPI bias, as measured from the regressions with the best fit, has fluctuated over the entire century. It was only -0.1 percent per year between 1888 and 1919 before rising to 0.7 percent per year between 1919 and 1935. Annual CPI bias was 0.4 percent between 1960 and 1972, rose to 2.7 percent between 1972 and 1982, and then declined to 0.6 percent between 1982 and 1994. What explains the observed pattern of CPI bias?

The CPI bias may have been greater in the 1920s than from 1890 to 1919 because many new consumer goods were introduced in the 1920s and they were only slowly introduced into the CPI. For example, radio sales were insignificant in 1919 but rose eightfold between 1923 and 1929 and continued to rise even during the Great Depression (Owen 1969 , p. 88). The rise of electricity in the home led to the widespread diffusion of such other appliances as refrigerators. The growth of car ownership allowed consumers to move to cheaper suburban land and shop at a wider variety of stores, including chain stores. Chain stores

\footnotetext{
${ }^{11}$ Picking 1981 as the endpoint implies that CPI bias was only 0.6 percent per year between 1972 and 1981, but it also implies that CPI bias was 21 percent between 1981 and 1982.
} 
grew rapidly in the 1920s and became the standard instruments for mass retailing (Chandler 1977, p. 233). But refrigerators were introduced into the CPI only in 1934, new autos in 1940, and used autos in 1952. Other goods that became common in the 1920s but were only slowly introduced into the CPI include lightbulbs, washing machines, vacuum cleaners, and auto repair and supplies (see U.S. Bureau of Labor Statistics 1940; National Bureau of Economic Research 1961).

The CPI bias may also have risen in the 1920s and early 1930s relative to the 1910s because of the treatment of housing in the CPI. Prior to 1953, when a homeowners component was first introduced into the CPI, weights for the rent index were computed on the basis of the share of expenditures devoted to rent for renters and the share of expenditures devoted to maintenance costs (mortgages, taxes, repairs, ground rent, and financing charges) for homeowners. Price data were obtained only for rents, and homeowners' maintenance costs were assumed to follow the same path as rents. ${ }^{12}$ Because swings in housing prices are larger than swings in rents, using rents imparts a downward bias to the CPI during the housing boom in the first half of the 1920s and an upward bias from the 1925 peak to the 1935 trough in the housing market. ${ }^{13}$

The Boskin Commission (Boskin et al. 1998) estimated that the biggest source of CPI bias between 1975 and 1994 was the late introduction of new goods into the CPI and quality improvements in existing goods. The postwar pattern of higher bias in the 1970s than in the 1960s or 1980s may arise from the greater price volatility of the 1970s relative to the 1960s (Baily 1981) and from extensive improvements made to the CPI in the 1980s (see Greenlees and Mason [1996] for a full list). The largest improvement occurred in 1983 when the homeowners component changed from one based on house prices, mortgage interest rates, property taxes and insurance, and maintenance costs to one based on the rental equivalent of shelter. The homeowners component effectively counted housing prices twice: once in the house price index and once in the mortgage interest rate index. In addition, the old homeowners component also failed to account for the tax deductibility of mortgages. Combined with the high inflation of the 1970s, this led to substantial subsidies in some tax brackets. Dougherty and Van Order (1982) estimate that between 1972 and 1980, mismeasurement in the costs of housing led to an annual CPI bias of roughly 2 percent. Comparing a

${ }^{12}$ See the February and April 1956 Monthly Labor Review for a discussion of housing costs in the CPI.

${ }^{13}$ See Bolch, Fels, and McMahon (1971) for a description of the housing market. Additional biases are likely to arise in the creation of weights. The rapid growth in mortgages in the 1920s increased the rental index's weight in the CPI, even though the only true change was the method of financing house purchases. Provided that the price of rent is less than that of nonrent, this will impart a downward bias to the CPI. 
- Revised Estimate
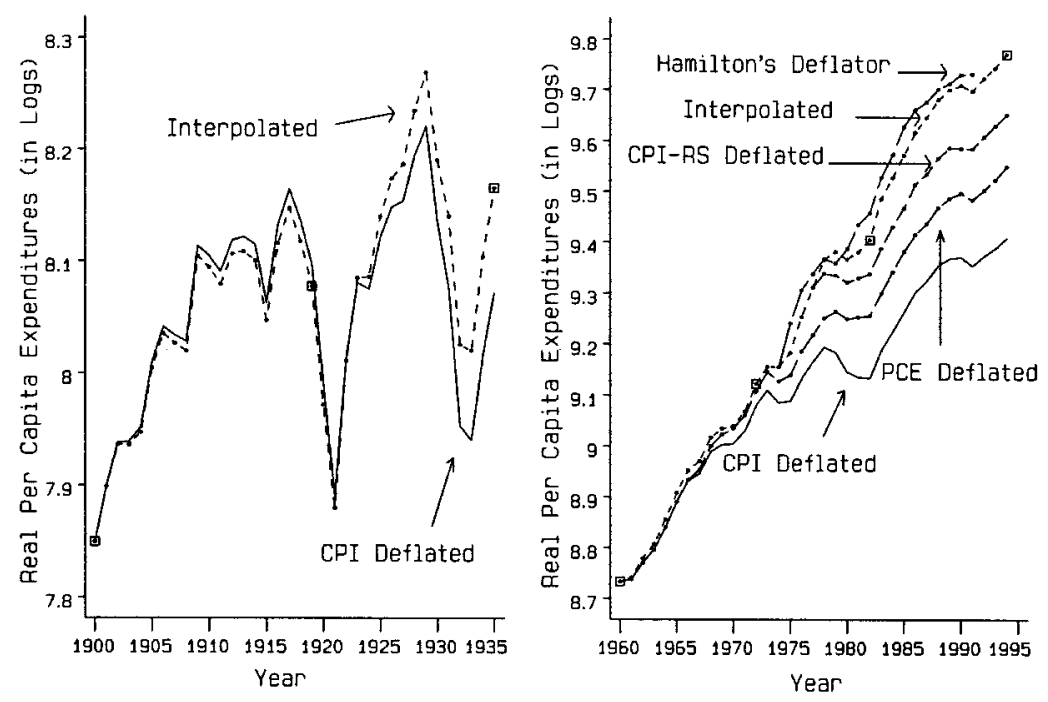

FIG. 2.--Revised real personal expenditures per capita, 1900-1994. All numbers are in constant 1982-84 dollars. The "revised estimate" is based on the average annual bias calculations presented in this paper. The "interpolated" series is based on the average annual bias estimates between the revised estimate endpoints. The CPI-deflated estimate is deflated by the usual CPI. The CPI-RS-deflated expenditures are deflated by the CPI recalculated back to 1978 using procedures in place in 1998 (Stewart and Reed 1999). It is linked to the interpolated series in 1977. Hamilton's (2001) deflator is based on his annual bias corrections beginning in 1975. Estimates are linked to the interpolated series in 1974. Current-dollar estimates for 1929-97 are taken from the NIPA and were obtained as a machine-readable file from the Dept. of Commerce. Total expenditures and expenditures prior to 1929 are taken from Lebergott (1996, pp. 148-53). Expenditures include not only those of individuals but also those of nonprofit institutions, private trust funds, and private health and welfare funds.

CPI recalculated using the methods in place in 1998 with the actual CPI suggests that annual bias between 1977 and 1982 was 1.3 percent and between 1982 and 19940.4 percent (Stewart and Reed 1999), with the treatment of housing accounting for most of the bias between 1977 and 1982.

\section{Implications}

Estimates of CPI bias suggest that we have mismeasured growth rates during the 1920s and 1930s and during the 1970s and 1980s. The first panel of figure 2 shows that real personal expenditures per capita were considerably higher in 1935 than in 1919, not lower, once I account for 
CPI bias. (The CPI bias is estimated from the food at home regression.) Instead of falling at a rate of -0.2 percent per year between 1919 and 1935 , real expenditures rose by 0.5 percent per year. Increases in the standard of living during the 1920s may have been so high that even the income shock of the Great Depression was not enough to reduce per capita expenditures to 1919 levels. Growth rates during the Great Depression could also have been better than indicated by the usual income numbers. Even during the Great Depression the proportion of families owning radios and refrigerators increased (Owen 1969, p. 89; Lebergott 1993, p. 113).

The second panel of figure 2 implies that there was no economic slowdown in the 1970s, once I account for CPI bias. (Again, CPI bias is estimated from the food at home regression.) Personal consumption expenditures per capita grew by 4.0 percent between 1960 and 1972, by 4.0 percent between 1972 and 1982, and by 3.7 percent between 1982 and 1994. In contrast, personal consumption per capita deflated by the CPI grew by 3.5 percent between 1960 and 1972, 0.6 percent between 1972 and 1982, and 2.6 percent between 1982 and 1994. When the personal consumption expenditure deflator is used, growth rates in those years were 3.8 percent, 1.6 percent, and 2.8 percent, respectively. The second panel of figure 2 also illustrates movements in per capita personal consumption expenditures when the CPI is recalculated back to 1977 using the methods in place in 1998 (Stewart and Reed 1999) and when Hamilton's (2001) bias corrections for 1974-91 are used. Recalculating the CPI leads to lower per capita expenditures by 1994 (annual growth rates between 1982 and 1994 would be only 3.1 percent). Using Hamilton's bias corrections leads to annual growth rates of 5.0 percent between 1974 and 1982 and 3.5 percent between 1982 and 1991.

\section{Conclusion}

This paper has used consumer expenditure surveys from 1888 to 1994 to provide the first estimates of overall CPI bias prior to the 1970s and to reassess long-run growth rates in per capita income. The CPI bias was small between 1888 and 1919 and between 1960 and 1972 but was high in the 1920s, 1970s, and 1980s. The CPI bias was -0.1 percent per year between 1888 and 1919 and rose to 0.7 percent per year between 1919 and 1935. Annual CPI bias was 0.4 percent in the 1960s and then rose to 2.7 percent between 1972 and 1982 before falling to 0.6 percent between 1982 and 1994. Overall, bias between 1972 and 1994 was 1.6 percent per year, in the upper end of the Boskin Commission's (Boskin et al. 1998) range of 0.8-1.6 percent per year and similar to Nordhaus's (1997) and Hamilton's (2001) respective estimates of 1.5 and 1.6 percent per year. Estimated annual bias for 1972-82 and 1982-94 is identical 
to Hamilton's annual bias estimates of 2.7 percent between 1974 and 1982 and 0.6 percent between 1982 and 1991.

Both the 1961 Stigler Commission (National Bureau of Economic Research 1961) and the Boskin Commission (Boskin et al. 1998) concluded that the biggest defect in the CPI was its failure to account adequately for new goods and improvements in existing goods. Dougherty and Van Order's (1982) and Stewart and Reed's (1999) findings imply that the CPI's biggest failure has been its treatment of the homeowners housing component and that these problems were aggravated by the high inflation rates of the 1970s. Improvements in the calculation of the CPI, particularly the homeowners component, help explain the decline in CPI bias in the 1980s. It is harder to identify the biggest source of bias in the prewar years. The large swings in housing prices may play a role. Quality-adjusted price indices of specific goods (e.g., Nordhaus 1997; Raff and Trajtenberg 1997) and the timing of the prewar increase in bias (coinciding with the consumer revolution of the 1920s) suggest that the failure to account for the introduction of new goods is likely to be a large source of bias in the 1920s as well.

This paper's findings suggest that we are underestimating real annual growth rates between 1919 and 1935 and after 1972. Correcting for CPI bias (estimated using food at home as an indicator) and recalculating growth rates suggests that, despite the Great Depression, real per capita personal expenditures were rising by 0.6 percent per year between 1919 and 1935 and that growth rates were as high in the 1970s as in the 1960s (4.0 percent per year). These revised rates undoubtedly underestimate increases in living standards between 1919 and 1935 because they account for CPI bias arising only from the late introduction of new goods into the CPI, price mismeasurement, the increased durability of existing goods, consumer substitution, and changes in the distribution network. They do not account for quality changes.

Many historians (e.g., Schlesinger 1957, p. 135; Dobson 1988, pp. 248-49) have argued that the prosperity of the 1920s was "flawed" because employers and investors were the primary beneficiaries whereas workers received only partial compensation for increases in productivity. But if the CPI was biased upward, then we are underestimating the growth in workers' incomes in the 1920s.

\section{Data Appendix}

\section{A. The Consumer Expenditure Surveys}

The prewar consumer surveys are generally comparable with each other and with the postwar surveys. All provided a thorough accounting of family sources of income and outlays of that income and were extensively checked for completeness and consistency. All utilized roughly similar interview techniques: mul- 
tiple visits, strong encouragement to keep written records, and the use of home surroundings to stimulate accurate recall of expenditure data. All used schedules that strongly resembled each other. And trends in the budget shares of most broad categories of goods in all the surveys are broadly consistent with the NIPA. There are, however, differences in population coverage.

In 1888-90, the sample was limited to workers in nine protected industries (bar iron, pig iron, steel, bituminous coal, coke, iron ore, cotton textiles, woolens, and glass) and appears to have been stratified by the proportions employed in each industry. Twenty-three states were covered, none of them in the West. Sample families were selected from employer records and were limited to families of two or more persons.

Families from the 1917-19 study were also selected from employer records and were restricted to those in which both spouses and one or more children were present, salaried workers did not earn more than $\$ 2,000$ a year $(\$ 13,245$ in 1982-84 dollars), families had resided in the same community for a year prior to the survey, families did not take in more than three boarders, families were not classified as either slum or charity, and non-English-speaking families had been in the United States five or more years. Ninety-nine cities in 42 states were covered.

The 1935-36 Consumer Purchases Study was limited to native-born husband and wife families in which families in metropolises and white families in large cities had a minimum income of at least $\$ 500$ (\$3,650 in 1982-84 dollars) and families in other cities had one of at least $\$ 250$ (\$1,825 in 1982-84 dollars). There was no upper income limit. The survey covered the self-employed as well as wage and salary workers. The communities covered by the study include 51 cities, 140 villages, and 60 farm counties, representing 30 states. Both urban and farm families were covered. Although the postwar consumer expenditure surveys are representative samples of the population, they were collected under different methodologies. The 1960-61 survey collected expenditures using annual recall. The 1972-73 survey collected data on a quarterly basis over two different years, but the data were then totaled to obtain annual values. Since 1980 the consumer expenditure surveys have been yearly and have used a rotating sample in which consumer units are interviewed once each quarter. Data are annualized in the estimation. The first two years of the quarterly data are considered less reliable than subsequent collections. The most consistent data begin in 1984 (Triplett 1997). Trends in food shares are broadly consistent with the NIPA data, with the exception of 1980-82, which shows a sharp decline in the food share in the consumer expenditure surveys.

The questions asked about spending on specific recreational items varied by survey. Only two questions were asked about recreational expenditures in 1888-90. One was about expenditures on books and newspapers and the other was about expenditures on the broad category of amusements and vacations. By 1917, families were already asked a much richer set of questions, including the total cost of purchased musical instruments, records, and rolls for player pianos and organs and of toys, sleds, and carts and the individual cost of movies, plays, dances, pool, excursions, vacations, books, and newspapers. In 1935-36, households were queried about family expenditures on books; newspapers; games or sports equipment; radio purchases and maintenance; musical instruments; movies; plays, concerts, and lectures; spectator sports; dances, circuses, and fairs; sheet music and records; photographic equipment; toys; pets; entertainment; and social and recreational club dues. Recreational categories in the 1960 machine-readable data are highly aggregated. The individual categories 
consist only of (1) television; (2) radio, phonographs, musical instruments, and so forth; (3) spectator admissions; (4) participant sports; (5) a miscellaneous category that includes club dues, hobbies, pets, toys, and recreation out of the home city; and (6) reading. By 1972 the individual categories become too extensive to itemize, ranging from country club memberships to electrical equipment to music lessons to swimming pool maintenance. Recreational expenditures in 1972-73 are understated relative to 1960-61 because some of the transportation expenditures included in 1960-61 in recreation were not included in 1972-73. In 1972-73, vacation expenditures on food, lodging, and travel are explicitly identified. However, by 1980, vacation expenditures on food, lodging, and gasoline are no longer identified. Because vacation travel was identified in neither the 1935-36 nor the 1980-94 surveys, I do not include it in my definition of total recreational expenditures.

\section{B. $\quad$ Price Indexes}

The Bureau of Labor Statistics (BLS) has been measuring changes in retail prices of goods and services purchased by city wage earners and clerical workers since 1913 using weights calculated from the consumer expenditure surveys. Indexes from 1800 through 1912 are estimated from price data from sources other than the BLS (see series E135-66 in U.S. Bureau of the Census [1975, pp. 210-11]).

The BLS provides regional price indexes up to the present day for urban consumers for all items and for food beginning in 1967 and for food at home, nonfood, and recreation beginning in $1978 .{ }^{14}$ Price indexes for earlier years are given for selected cities only. I weight the price indexes for cities on the basis of their populations to create regional price indexes. For 1917-50, I use the cities and price indexes given in Handbook of Labor Statistics: 1950 Edition (U.S. Bureau of the Census 1951) to create regional price indexes for all items and for all food. For 1950-67 for all items and for food, for 1953-78 for food at home, and for 1960-78 for recreation, I use the smaller sample of cities for which continuous price indexes are available. ${ }^{15}$ The food index used in the estimation is based on the price of all food. The results were not sensitive to the use of a price index for food at home instead of all food.

\section{References}

Baily, Martin Neil. "Productivity and the Services of Capital and Labor." Brookings Papers Econ. Activity, no. 1 (1981), pp. 1-50.

Bolch, Ben; Fels, Rendigs; and McMahon, Marshall E. "Housing Surplus in the 1920's?” Explorations Econ. Hist. 8 (Spring 1971): 259-83.

Boskin, Michael J.; Dulberger, Ellen R.; Gordon, Robert J.; Griliches, Zvi; and Jorgenson, Dale W. "Consumer Prices, the Consumer Price Index, and the Cost of Living." J. Econ. Perspectives 12 (Winter 1998): 3-26.

Chandler, Alfred D., Jr. The Visible Hand: The Managerial Revolution in American Business. Cambridge, Mass.: Belknap Press, Harvard Univ. Press, 1977.

${ }^{14}$ Price indexes for all items, food, and nonfood are available from the BLS web site (http://www.bls.gov). Price indexes for recreation are available from various issues of CPI Detailed Report.

${ }^{15}$ For all items and food, see the BLS web site (http://www.bls.gov). For recreation, see various issues of CPI Detailed Report and Consumer Price Index. 
Costa, Dora L. The Evolution of Retirement: An American Economic History, 1880-1990. Chicago: Univ. Chicago Press (for NBER), 1998.

—. "American Living Standards, 1888-1994: Evidence from Consumer Expenditures." Working Paper no. 7650. Cambridge, Mass.: NBER, April 2000.

Dobson, John M. A History of American Enterprise. Englewood Cliffs, N.J.: Prentice Hall, 1988.

Dougherty, Ann, and Van Order, Robert. "Inflation, Housing Costs, and the Consumer Price Index." A.E.R. 72 (March 1982): 154-64.

Greenlees, John S., and Mason, Charles C. "Overview of the 1998 Revision of the Consumer Price Index." Monthly Labor Rev. 119 (December 1996): 3-9.

Hamilton, Bruce W. "Using Engel's Law to Estimate CPI Bias." A.E.R. 91 (June 2001): 619-30.

Hausman, Jerry A.; Newey, Whitney K.; and Powell, J. L. "Nonlinear Errors in Variables: Estimation of Some Engel Curves." J. Econometrics 65 (January 1995): 205-33.

Lebergott, Stanley. Pursuing Happiness: American Consumers in the Twentieth Century. Princeton, N.J.: Princeton Univ. Press, 1993.

- Consumer Expenditures: New Measures and Old Motives. Princeton, N.J.: Princeton Univ. Press, 1996.

Nakamura, Leonard. "Is the U.S. Economy Really Growing Too Slowly? Maybe We're Measuring Growth Wrong." Fed. Reserve Bank Philadelphia Bus. Rev. (March-April 1997), pp. 3-14.

National Bureau of Economic Research. Price Statistics Review Committee. The Price Statistics of the Federal Government: Review, Appraisal, and Recommendations. General Series, no. 73. New York: NBER, 1961.

Nordhaus, William D. "Do Real-Output and Real-Wage Measures Capture Reality? The History of Lighting Suggests Not." In The Economics of New Goods, edited by Timothy F. Bresnahan and Robert J. Gordon. Chicago: Univ. Chicago Press (for NBER), 1997.

Owen, John D. The Price of Leisure: An Economic Analysis of the Demand for Leisure Time. Rotterdam: Rotterdam Univ. Press, 1969.

Raff, Daniel M. G., and Trajtenberg, Manuel. "Quality-Adjusted Prices for the American Automobile Industry: 1906-1940." In The Economics of New Goods, edited by Timothy F. Bresnahan and Robert J. Gordon. Chicago: Univ. Chicago Press (for NBER), 1997.

Sabelhaus, John. Consumer Expenditure Survey Family Level Extracts-1980:1-1995: 1. http://www.nber.org, 1996.

Schlesinger, Arthur M. The Crisis of the Old Order, 1919-1933. Boston: Houghton Mifflin, 1957.

Stewart, Kenneth J., and Reed, Stephen B. "Consumer Price Index Research Series Using Current Methods, 1978-98.” Monthly Labor Rev. 122 (June 1999): 29-38.

Triplett, Jack E. "Measuring Consumption: The Post-1973 Slowdown and the Research Issues." Fed. Reserve Bank St. Louis Rev. 79 (May/June 1997): 9-42.

U.S. Bureau of the Census. Historical Statistics of the United States, Colonial Times to 1970. Washington: Government Printing Office, 1975.

U.S. Bureau of Labor Statistics. "The Bureau of Labor Statistics' New Index of Cost of Living." Monthly Labor Rev. 51 (August 1940): 367-405.

- Handbook of Labor Statistics: 1950 Edition. Bulletin no. 1016. Washington: Government Printing Office, 1951.

U.S. Department of Labor. Cost of Living of Industrial Workers in the United States 
and Europe, 1888-1890. ICPSR 7711. 3d ed. Ann Arbor, Mich.: Inter-university Consortium Polit. and Soc. Res., 1986.

. Bureau of Labor Statistics. Consumer Expenditure Survey, 1960-1961. ICPSR 9035. Ann Arbor, Mich.: Inter-university Consortium Polit. and Soc. Res., 1983.

. Cost of Living in the United States, 1917-1919. ICPSR 8299. Ann Arbor, Mich.: Inter-university Consortium Polit. and Soc. Res., 1986.

. Survey of Consumer Expenditures, 1972-1973. ICPSR 9034. Inter-university Consortium Polit. and Soc. Res., 1987.

U.S. Department of Labor, Bureau of Labor Statistics, and U.S. Department of Agriculture, Bureau of Home Economics. Study of Consumer Purchases in the United States, 1935-1936. ICPSR 8908. Ann Arbor, Mich.: Inter-university Consortium Polit. and Soc. Res., 1999. 